\title{
Viewpoint
}

\section{Why the misinformation, shame and guilt associated with coronavirus?}

\author{
Janet Michel ${ }^{1}$, Stephen Reid ${ }^{2}$, Alois Dörlemann ${ }^{3}$, Marcel Tanner $^{1}$ \\ 1 Epidemiology and Public Health Department, Swiss Tropical and Public Health Institute, Basel, Switzerland, 2 Primary Health Care Directorate, \\ University of Cape Town, Cape Town, South Africa, ${ }^{3}$ Health Focus, Potsdam, Germany \\ Keywords: misinformation, covid-19
}

https://doi.org/10.29392/001c.17364

\section{Journal of Global Health Reports}

Vol. 4, 2020

\begin{abstract}
Mass media information, scientific articles and reports on measures to prevent infection are confusing at the least and figures from China and Iran lack cohesion. Reports suggest that Chinese scientists knew about coronavirus in early December 2019, but were told to conceal evidence by government. It is alleged that as cover-up, government officials intentionally withheld information that hospital workers had been infected by patients, a sign of how highly contagious the virus is. Researchers were also instructed to keep quiet and even ordered to destroy samples. Similar reports are also suggesting that Iran is under-reporting cases. In Africa, employees from a hospital in Zambia have also reported having been ordered not to speak publicly. They reported witnessing people who recently returned from China with coughs not being put in quarantine. Similar denials and cover-up strategies were seen in the 90s during the AIDS crisis. The guilt and shame that was associated with HIV were thought to have been associated with the intimate nature of transmission (mostly sexual) even though others got it through other routes including mother to child transmission etc. SARS-CoV-2 has not yet been proven to be intimately transmitted though having been isolated from semen. Why then the misinformation, shame, and guilt? How can countries move from the cover-up, blame games to responsibility as the virus defies containment? Some questions remain; How can cover-ups be prevented? How can governments be held accountable for cover-ups, misinformation, etc?
\end{abstract}

Mass media information, scientific articles and reports on measures to prevent infection are confusing at the least and figures from China and Iran lack cohesion. ${ }^{1,2}$ Confusing enough is the figure that $8 \%$ of Iran`s law makers, among them vice president and trade minister have tested positive. ${ }^{3,4}$ Are all these cases contacts of the deputy health Minister that tested positive $?^{4}$ Of concern are indications that the authorities have refused to impose quarantines, regarding them as old fashioned, thereby leaving high traffic sites like shrines in the hotbed towns of the virus open. ${ }^{4}$

Reports suggest that Chinese scientists knew about coronavirus in early December 2019, but were told to conceal evidence by government. ${ }^{2}$ It is alleged that as cover-up, government officials intentionally withheld information that hospital workers had been infected by patients, a sign of how highly contagious the virus is. ${ }^{2,5}$ Researchers reported being instructed to keep quiet and even ordered to destroy samples. ${ }^{2,5}$ Similar reports are also suggesting that Iran is under-reporting cases. ${ }^{4}$ In Africa, employees from a hospital in Zambia have also reported having been ordered not to speak publicly. They reported witnessing people who recently returned from China with coughs not being put in quarantine. ${ }^{6}$ Some reported a critical shortage of testing kits and protective gear. ${ }^{6,7}$ Could that be a source of shame too?

\section{WHY THE MISINFORMATION, SHAME AND GUILT?}

Transparency is not a window that can be opened and shut at the state`s will. ${ }^{8}$ Reports suggest that bodies were cremated in Wuhan without death records,, making it difficult to tell how fatal the virus really was. ${ }^{8}$ Similar denials and cover up strategies were seen in the 90s during the AIDS crisis. ${ }^{8-10}$ The guilt and shame that were associated with HIV was thought to have been associated with the intimate nature of transmission (mostly sexual) even though others got it through other routes including mother to child transmission. ${ }^{11}$ SARS-CoV-2 has not yet been proven to be sexually transmitted. ${ }^{12,13}$ though it has been isolated in semen. ${ }^{14}$ Could that be the reason for the misinformation, shame and guilt? The very origins of SARS-CoV-2 are disputed ${ }^{15,16}$ with some suggesting a lab origin and others refuting it. Could that too be the source of shame and guilt? How can countries move from cover-up and blame games to responsibility as the virus defies containment? ${ }^{6}$ Confusingly, SARS-CoV-2 infections have mostly been reported where testing is feasible. Even with substantial confirmed cases, low SARS-CoV-2 infection and mortality rates in Africa continues to boggle health experts. ${ }^{17,18}$ Is it faulty detection, climatic conditions or genes ${ }^{18}$ Nobody knows. Bearing in mind the close trade links between China and Africa, and the fact that one million Chinese live in Africa, and 80000 African students are in China, should this be left to time and chance for us to know what is going on? ${ }^{18}$ Algeria, 
Egypt and South Africa were initially identified as the only countries with the best prepared health systems and the least vulnerable on the continent with regards to SARS$\mathrm{CoV}-2 .{ }^{18}$ Africa seems to have overcome the first wave without the initially projected overwhelmed hospitals and high mortality scenarios. ${ }^{17,18}$ The pandemic though, seems still far from being over.

\section{SUGGESTIONS TO AID IN UNDERSTANDING THE SARS- COV-2 PANDEMIC}

The current data on SARS-CoV-2 is anecdotal. We need reliable data hence we propose the following;

- Setting up of prospective cohort studies in communities in affected countries ahead of the virus to ascertain risk

- Designing and conducting randomized SARS-CoV-2 PCR testing with a significant number of samples in populations in regions with fewer cases reported so far

- Designing and conducting randomized SARS-CoV-2 PCR testing among health care workers in settings where fewer cases of SARS-CoV-2 infection have been reported so far.

- Analyzing preventive measures taken to avoid infection among health care workers, testing a significant number of health care workers on SARS-CoV-2, and in parallel including them in a knowledge, attitude and practice (KAP) study in order to get reliable information on their knowledge, attitudes and practices related to SARS-CoV-2 infection and use of protecting measures.

\section{CONCLUSION}

Reported new efforts to increase SARS-CoV-2 testing capabilities at state and local labs and the plans to streamline the process for private development of test kits are welcome. ${ }^{19}$ In the same vein, we propose efforts to design and conduct studies to generate reliable data in a scientific and transparent manner, so as to increase the understanding of SARS-CoV-2. United Kingdom has released figures showing that the virus seems to be defying containment ${ }^{11}$ and a sec- ond lockdown is looming. ${ }^{20}$ Some questions remain; How can cover-ups be prevented? How can governments be held accountable for cover-ups, disinformation and misinformation. ${ }^{21}$

\section{DECLARATIONS}

\section{DISCLAIMER}

The views expressed in this viewpoint are those of the authors and do not reflect the views of the journal or the publisher.

\section{FUNDING}

None

\section{AUTHORSHIP CONTRIBUTIONS}

JM had the initial concept and SR, AD and MT contributed to writing and revision of further drafts. All authors contributed and meet the ICMJE criteria for authorship and have read and approved final draft

\section{COMPETING INTERESTS}

The authors alone are responsible for the views expressed in this view point and they do not necessarily represent the views of the Universities or Institutions they are affiliated to. The authors declare no competing interests.

\section{CORRESPONDENCE TO:}

Janet Michel, $\mathrm{PhD}$

Epidemiology and Public Health Department

Swiss Tropical and Public Health Institute

Basel, Switzerland

E-mail: janetmichel71@gmail.com

Submitted: September 23, 2020 GMT, Accepted: September 24, 2020 GMT 


\section{REFERENCES}

1. Fassihi F, Gladstone R. Confusion and

Contradiction Reign in Iran's Coronavirus Reporting.

New York Times. https://www.nytimes.com/2020/02/2

8/world/middleeast/coronavirus-iran-confusion.html. Published 2020. Accessed September 23, 2020.

2. China officials ordered coronavirus cover-up, report says. https://nypost.com/2020/02/29/china-officials-k new-of-coronavirus-in-december-ordered-cover-up-r eport-says/. Accessed March 5, 2020.

3. Iranian trade minister tests positive for coronavirus. https://www.aa.com.tr/en/latest-on-coro navirus-outbreak/iranian-trade-minister-tests-positi ve-for-coronavirus/1754105. Accessed March 5, 2020.

4. Rahimpour R. Coronavirus: Iran's deputy health minister tests positive as outbreak worsens. BBC. $\underline{\text { http }}$ s://www.bbc.com/news/world-middle-east-51628484. Published 2020. Accessed September 23, 2020.

5. Virologist Dr. Li-Meng Yan Claims Coronavirus Lab “Cover-Up” Made Her Flee China / Loose Women. http s://www.youtube.com/watch?v=7Lq3_rsB/9w.

Accessed September 22, 2020.

6. "We're definitely not prepared": Africa braces for new coronavirus. STAT. February 2020. https://www.s tatnews.com/2020/02/08/africa-braces-for-new-coron avirus/. Accessed March 5, 2020.

7. Powell-Jackson T, King JJC, Makungu C, et al. Infection prevention and control compliance in Tanzanian outpatient facilities: a cross-sectional study with implications for the control of COVID-19. Lancet Glob Health. 2020;8(6):e780-e789. doi:10.101 6/S2214-109X(20)30222-9

8. Palmer J. Chinese Officials Can’t Help Lying About the Wuhan Virus. Foreign Policy. https://foreignpolic y.com/2020/02/03/wuhan-coronavirus-coverup-lies-c hinese-officials-xi-jinping/. Accessed March 5, 2020.

9. Kalichman SC, Eaton L, Cherry C. “There is no Proof that HIV Causes AIDS": AIDS Denialism Beliefs among People Living with HIV/AIDS. J Behav Med. 2010;33(6):432-440. doi:10.1007/s10865-010-9275-7

10. Smith TC, Novella SP. HIV Denial in the Internet Era. PLoS Med. 2007;4(8). doi:10.1371/journal.pmed.0 $\underline{040256}$

11. The Shame and Guilt of Living With HIV. HuffPost. https://www.huffpost.com/entry/the-sham e-and-guilt-of-living-with-hiv b 8512814. Published November 9, 2015. Accessed March 5, 2020.
12. Business Standard. Can coronavirus spread through cough and sex. 2020. https://www.business-s tandard.com/article/current-affairs/can-coronavirusspread-through-cough-and-sex-here-s-all-you-needto-know-120030400170_1.html. Accessed September 23,2020

13. Lopes GP, Vale FBC, Vieira I, da Silva Filho AL, Abuhid C, Geber S. COVID-19 and Sexuality: Reinventing Intimacy. Arch Sex Behav. July 2020:1-4. doi:10.1007/s10508-020-01796-7

14. Li D, Jin M, Bao P, Zhao W, Zhang S. Clinical Characteristics and Results of Semen Tests Among Men with Coronavirus Disease 2019. JAMA Netw Open. 2020;3(5):e208292-e208292. doi:10.1001/jama networkopen.2020.8292

15. The Case Is Building That COVID-19 Had a Lab Origin. Indep Sci News Food Health Agric Biosci News. https://www.independentsciencenews.org/heal th/the-case-is-building-that-covid-19-had-a-lab-orig in/. Published June 2, 2020. Accessed September 22, 2020.

16. May $12 \mathrm{MVB}|\mathrm{NW}| \mathrm{CN} \mid$, 2020. Scientists: “Exactly zero" evidence COVID-19 came from a lab. CIDRAP. $h$ ttps://www.cidrap.umn.edu/news-perspective/2020/0 $\underline{5 / \text { scientists-exactly-zero-evidence-covid-19-came-la }}$ b. Accessed September 22, 2020.

17. Global Health NOW: Good News, Bad News for Africa; COVID-19's Extra Burden on Women; and CDC Pulls Airborne Guidance -

janetmichel71@gmail.com - Gmail.https://mail.goog le.com/mail/u/0/?tab=rm\&ogbl\#inbox/FMfcgxwIXxtF mzXxBzMhKmbLVXOMVCJK. Accessed September 22, 2020 .

18. With only three official cases, Africa's low coronavirus rate puzzles health experts. France 24 . ht tps://www.france24.com/en/20200301-with-only-thre e-official-cases-africa-s-low-coronavirus-rate-puzzle s-health-experts. Published March 1, 2020. Accessed March 5, 2020.

19. Feuer W. Amid testing concerns, US officials unveil new coronavirus test kits and streamline commercial development. CNBC. https://www.cnbc.c om/2020/02/28/amid-testing-capacity-concerns-cdcunveils-new-coronavirus-test-kits.html. Published February 28, 2020. Accessed March 5, 2020.

20. Lockdown looms in Britain as Johnson admits to second wave. https://www.afr.com/world/europe/lock down-looms-in-britain-as-johnson-admits-to-secon d-wave-20200919-p55x66. Accessed September 23, 2020. 
21. COVID-19 pandemic: countries urged to take stronger action to stop spread of harmful information. https://www.who.int/news-room/detail/ 23-09-2020-covid-19-pandemic-countries-urged-to-t ake-stronger-action-to-stop-spread-of-harmful-infor mation. Accessed September 24, 2020. 